\title{
CONSUMERS' APPEALS FROM PUBLIC SERVICE COMMISSION RATE ORDERS
}

\author{
T. RICHARD WITMER*
}

I

$\mathrm{O}$

NE WOULD hesitate to say that it is a cardinal principal of constitutional law that the due process clause of the Fourteenth Amendment protects only those who, however strong they are financially, are numerically weak when heads are counted; that if plaintiff is one of the many he not only must exhaust his remedies at the polls before resorting to the courts but must confine himself to those remedies. One would rather believe that judicial review, if it is to exist at all, is available whenever there is need of protecting people, whether few or many, from those who, by election or otherwise, acquire control of the coercive powers of the state. Yet, when set side by side, Sands v. Manistee River Improvement Co. ${ }^{1}$ and Chicago, M. E St. P. R. Co. v. Minnesota ${ }^{2}$ lend

* Assistant Professor of Law, Yale University.

I 23 U.S. 288 (1887). In a suit by the plaintiff to recover tolls fixed by state authority, the defendant-consumer requested the trial court to instruct the jury "That the statute of the State, under which the plaintiff was organized and the tolls were fixed, was in conflict with the [due process] clause of the Fourteenth Amendment .... in authorizing the Board of Control to fix the rates of toll without notice to the parties interested, or affording them any opportunity of contesting the validity or propriety of such tolls, either in the first instance or afterwards." Instruction refused; verdict and judgment for the plaintiff affirmed by state supreme court. On appeal, held: affirmed. Per Field, J.: "The whole subject is one of administrative regulation, in which a certain amount of discretionary authority is necessarily confided to officers entrusted with its execution. Should there be any gross injustice in the rate of tolls fixed, it would not, in our system of government, remain long uncorrected." Compare Wichita Railroad \& Light Co. v. Public Utilities Com'n of Kansas, 260 U.S. 48 (1922) (contract-consumer is entitled to an explicit finding by the commission that its rates are unreasonably low before they can be raised; so under the applicable Kansas statute [but on this Consolidated Flour Mills Co. v. Kansas Gas \& Electric Co., Irg Kan. 47, 237 Pac. I037 (I925) is expressly contra] and "general principles of constitutional government"); Attleboro Steam \& Electric Co. v. Narragansett Electric Lighting Co., 295 Fed. 895 (D.C. R.I. 1924). With these cases in turn, compare Southern Oil Corp. v. Yale Natural Gas Co., 89 Okla. I21, 214 Pac. 13I (1923), aff'd 266 U.S. 583 (1924) (contract-consumer not entitled to notice and hearing when rates are abrogated).

${ }^{2}$ I 34 U.S. 4 I 8 (1890). Suit by the state to compel the railroad to conform to rates prescribed by the state commission. The state courts refused to try the issue of the reasonableness of the rates; the statute did not require a hearing by the commission. Held: reversed. "The question of the reasonableness of a rate of charge for transportation by a railroad company, involving as it does the element of reasonableness both as regards the company and as regards the public, is eminently a question for judicial investigation, requiring due process of law for its determination." 
an aura of veracity to such a summary statement as the first of these. And in an era when Chief Justice Waite's pronouncement, "For protection against abuses by legislatures the people must resort to the polls, not to the courts," 3 is admittedly a once-upon-a-time story in its own context, its reiteration in almost identical words by the Alabama court in a consumer's suit ${ }^{4}$ sounds a bit strange unless one attempts a reconciliation along that line.

In fact, though one may not set it down as doctrine, there has been a persistently different treatment by the courts of consumers who complain that rates have been set unconstitutionally high from that accorded utilities whose complaint is that they are unconstitutionally low. Such a consumer's complaint was the one that the Alabama court faced in 1937; such a complaint is the one that other courts as well have been confronted with and have handled in the same way. ${ }^{5}$ The consequence of their decisions is that "extortionate" has never risen to the dignity of "confiscatory."

It is not strange, of course, that the United States Supreme Court veered away from Chief Justice Waite's dictum during the period in which it did; if anything is strange it is that it took so long to do so. For those cases in which the new extension of judicial review was born were but a recapitulation, one may believe, of the development of twenty-five years before in the municipal bond cases. One case that must not be forgotten is that in which the Court's reporter, doing his best to preserve the amenities of his office, nevertheless thought it proper to suggest his own explanation of why the Court followed earlier rather than later Wisconsin decisions on which hinged the validity of such a bond issue:

And how far this departure from precedent [by the Wisconsin court] was owing to a truer conception of the nature of general and particular laws, and how far to the fact, that the judiciary of Wisconsin was a body elected by popular suffrage at short intervals, and which might have come to the bench suffused with the feelings and ideas and wishes of a constituency wishing to disown an obligation which it had been found much easier to contract than to pay, was a matter not seen perfectly alike by both sides. ${ }^{6}$

As surely as Shays' Rebellion frightened the nether-Fathers of the Constitution out of any love or respect for democracy which they may have

${ }^{3}$ Munn v. Mlinois, 94 U.S. I13, 134 (1877).

4 Birmingham v. Southern Bell Tel. \& Tel. Co., 234 Ala. 526, 533, r 76 So. 30 r, 306 (1937).

5 St. Paul Book \& Stationery Co. v. St. Paul Gaslight Co., I30 Minn. 7I, 153 N.W. 262 (Igr 5); Brooklyn Union Gas Co. v. New York City, 50 Misc. 450, 100 N.Y. Supp. 570 (S.Ct. Ig06), aff'd ir5 App. Div. 69, roo N.Y. Supp. 625 (Ig06), aff'd r 88 N.Y. 334, 8r N.E. I4I (1907); United States Light \& Heat Corp. v. Niagara Falls Gas \& Electric Light Co., 47 F. (2d) ${ }_{567}$ (C.C.A. 2 d I93I). Cf. Atlanta v. Ickes, 308 U.S. 517 (I939), affirming 26 F. Supp. 606 (D.C. 1939).

${ }^{6}$ Havemeyer v. Iowa County, 3 Wall. (U.S.) 294, 296 (1865). 
had, the restlessness of the Grangers confirmed the suspicions of some of the hither-Fathers that all could not be well if there were no check on popular government. ${ }^{7}$

Nor, apart from any belief that the Court may have entertained as to the efficacy of political action to protect the public at large, is it altogether strange that the results in the consumer cases have gone the way they have. It is undeniable that the courts, in this type of case, are faced with difficult problems if they grant the relief the consumer asks. It may be, of course, that the recent opinions of Mr. Justice Black ${ }^{8}$ and $\mathrm{Mr}$. Justice Frankfurter ${ }^{9}$ foretell the wiping out of the distinction, at least on the substantive side, by a discontinuance of judicial review at the suit of a utility. But in the meantime, unless one is willing, as Mr. Justice Stone recently suggested must sometimes be the case, "to substitute a rule for a reason" it is important to examine the articulate premises on which the result is built. For unless one accepts a pure doctrine of expediency-an overlooking of the irreparable harm of the transient present for the ameliorative lesson at the polls of the future-as the foundation of constitutional doctrine, it will not do, in our type of case, to say merely that the consumer ${ }^{11}$ has adequate representation in the public officials and is bound by

7 To catch a glimpse of the temper of some of the members of the Court at the time, consult Brewer, Protection to Private Property from Public Attack (189I); Swisher, Stephen J. Field, particularly 314-1 5, 382-83 (1930); Miller, Socialism and Society (1888), reprinted in Gregory, Samuel Freeman Miller 143-7I (1907).

8 Dissenting in McCart v. Indianapolis Water Co., 302 U.S. 419, 423 (1938); concurring in United Gas Public Service Co. v. Texas, 303 U.S. I23, I46 (1938).

9 Concurring in Driscoll v. Edison Light \& Power Co., 307 U.S. 104, I 22 (1939) ("The determination of utility rates-what may fairly be exacted from the public and what is adequate to enlist enterprise- does not present questions of an essentially legal nature in the sense that legal education and lawyers' learning afford peculiar competence for their adjustment. . . . . The only relevant function of law in dealing with this intersection of government and enterprise is to secure observance of those procedural safeguards in the exercise of legislative powers which are the historic foundations of due process").

so Curry v. McCanless, 307 U.S. 357, 367 (1939).

"I use the term "consumer" throughout to denote either an individual consumer, a consumers' association, or a municipality representing its citizens. On the last, see McIntire, Municipalities as Legal Representatives of Consumer Interests, 4 Legal Notes on Local Government 3 (1938). It need not be emphasized, of course, that in most cases the only "consumer" who will have the facilities for prosecuting an appeal of the kind here discussed is a municipality. Except for the largest industrial users, the expense to private persons is prohibitive. And we are still not a sufficiently consumer-minded country to expect much to happen by way of consumers' associations' appeals except, again, among commercial and industrial interests. So far as municipalities go, there is no concern in this article with those multitudinous cases arising out of disputes between cities and commissions over the latter's annulment of rates determined by franchise or contract. 
their acts. ${ }^{12}$ In the cases in which the doctrine is most frequently asserted, namely, those in which a consumer is refused permission by the courts to intervene in litigation between the utility and the rate-making body ${ }^{\mathrm{I} 3}$ or in which he seeks to litigate the company's charges while another suit is being carried on elsewhere between commission and utility, ${ }^{14}$ there is probably little objection to such a teaching, though there may be to its phrasing. Apart from other considerations that govern intervention and comity between courts, it is fair in both of these types to presume that the consumer is being fairly and vigorously represented. The application of the doctrine to those cases in which, during or after litigation, the utility

ז2 Birmingham v. Southern Bell Tel. \& Tel. Co., 234 Ala. 526, 533, I 76 So. 301, 306-7 (1937); United States Light \& Heat Corp. v. Niagara Falls Gas \& Electric Co., 47 F. (2d) 567,570 (C.C.A. 2 I I93 I); cf. Smith v. Illinois Bell Tel. Co., 270 U.S. 587, 592 (1926). With the cases cited in note $I 7$ infra, compare those holding that a consumer will not be heard to contest the reasonableness of rates lower than the maximum allowed by public authority. St. Paul Book \& Stationery Co. v. St. Paul Gaslight Co., r30 Minn. 71, 77, 153 N.W. 262, 265 (1915); Brooklyn Union Gas Co. v. New York City, r88 N.Y. 334, 8r N.E. I4I (r907); Underwood Lumber Co. v. Pelican Boom Co., 76 Wis. 76, 45 N.W. I8 (1890) (semble); Homestead Co. v. Des Moines Electric Co., 248 Fed. 439, 443 (C.C.A. 8th rgr8). See Griffith v. Vicksburg Water Works Co., 88 Miss. 371, 386, 40 So. IOI I, IOI3, (1906) ("We decline to follow the decision in Griffin v. Goldsboro Water Co. [ 122 N.C. 206, 30 S.E. 3 I9 (1898)] in holding that while a water company, which accepts an ordinance by which a maximum rate is fixed, is bound . . . yet such rates are not binding upon consumers, who have a right to litigate against unreasonable charges"). Cf. Winsor Coal Co. v. Chicago \& A.R. Co, 52 Fed. 7 I6, 720 (C.C. Mo. I892) ("In the absence of any affirmative action by the commissioners, the intendment of law arising from the legal presumption that public officers perform their duties should be that no complaint had arisen of unjust charges, or that the commissioners . . . . deemed the maximum fixed by the carrier and the legislature to be reasonable and just").

${ }_{13}$ New York City v. Consolidated Gas Co., 253 U.S. 2 I9 (I920); New York City v. New York Tel. Co., 26r U.S. 3 I 2 (I923); San Antonio Utilities League v. Southwestern Bell Tel. Co., 86 F. (2d) 584 (C.C.A. $5^{\text {th }}$ 1936), cert. den. 301 U.S. 682 (r937). Cf. Chicago v. Chicago Rapid Transit Co., 284 U.S. 577 (I93 I) (intervening city denied right to appeal after litigation resulting in injunction against rate order was dropped by state officers). In In re Engelhard \& Sons Co., 23 I U.S. 646 (IgI4), often cited as the leading case for this point, the lower court had allowed the petitioner to intervene for himself but had denied him the privilege of representing other consumers until he established their consent.

${ }_{14}$ Spring Valley Waterworks v. San Francisco, r 24 Fed. 574 (C.C. Cal. I903); Central of Georgia R. Co. v. Railroad Com'n of Alabama, r6r Fed. 925, 98r (C.C. Ala. rgo8), rev'd on other grounds r 70 Fed. 225 (C.C.A. $5^{\text {th }}$ rgog), cert. den. 2 I4 U.S. 52 I (1909); San Francisco Gas \& Electric Co. v. San Francisco, I64 Fed. 884 (C.C. Cal. r9o8); Pacific Tel. \& Tel. Co. v. Star Publishing Co., 2 F. (2d) I5I (D.C. Wash. 1924). Cf. Schneider v. New Amsterdam Gas Co., r 6 App. Div. 345, ror N.Y. Supp. 535 (rgo6); Pacific Tel. \& Tel.. Co. v. Agnew, 5 F. (2d) 22 I (C.C.A. 9th I925); Griffith v. Vicksburg Water Works Co., 88 Miss. 37 I, 40 So. IoI I (I906). Not all federal courts, however, have thought it necessary to protect their jurisdiction by enjoining such independent suits in the state courts. See Consolidated Gas Co. v. Mayer, I46 Fed. I 50 (C.C. N.Y. I906) and Richman v. Consolidated Gas Co., I86 N.Y. 209, 78 N.E. 87 I (I906), with which Buffalo Gas Co. v. Buffalo, I 56 Fed. 370 (C.C. N.Y. I907) should be compared. 
and the public representatives agree to compose their differences ${ }^{15}$ is decidedly closer to the doubtful line. And it is far from self-evident-particularly in the case of those commissions which, some students believe, have adopted or have been forced to adopt a "judicial" rather than an aggressively pro-consumer attitude ${ }^{\mathrm{r}}$-in the sort of case with which we are concerned that the rates, because they are made by public authority, ought to be so binding on the consumer that he may not, by himself, bring an independent suit. ${ }^{77}$ For here he is denying the adequacy of the representation and fighting against it. He is, in all likelihood, but one of many consumers over whom the commission has jurisdiction. Since few of its policies and fewer of its rate orders will hit him and his fellows at the same time, it is difficult to say that, except in the long run, a concerted opinion can be depended on to keep the commission in line. If, in this particular litigation, the consumer has been represented at all, it is because the court says that he has been, not because he has so chosen or acquiesced in the choice.

To support the result, the courts that have reached it have adduced a

is Wright v. Central Kentucky Natural Gas Co., 297 U.S. 537 (1936); O'Connell v. Pacific Gas \& Electric Co., r9 F. (2d) 460 (C.C.A. 9th 1927).

${ }^{16}$ Bauer, Effective Regulation of Public Utilities 359 (1925); Dimock, British and American Utilities: A Comparison, I Univ. Chi. L. Rev. 265, 27 I (I934); Mosher and Crawford, Public Utility Regulation 40 (I933) ("In the administration of their functions the most serious shortcomings of the commissions is the tendency to adopt a judicial attitude. . . . If regulation is to be made effective a changed attitude on the part of the typical commission is mandatory. The original conception of the commission as an administrative agency must be reborn . . .."); Porter, State Administration 402 (1938). Mosher and Crawford, op. cit. supra, at 57, describe the results of a survey made in 1930; interviewers in twenty-eight state capitals-they talked with "prominent and representative editors (newspaper), writers, or university professors"-found that in seventeen states the local commission was regarded as "utility-minded." in six as "public-minded," in two as "judicially-minded," and in three as an unknown quantity.

"It is, of course, true that some courts have held or intimated that publicly-prescribed rates are not, ipso facto, binding on consumers. Griffin v. Goldsboro Water Co., I 22 N.C. 206 , 30 S.E. 3 I9 (1898). See American Rio Grande Land \& Irrigation Co. v. Karle, 237 S.W. 358, 361 (Tex. Civ. App. 1922), writ of error dismissed 240 S.W. xv (1922); Salt Lake City v. Utah Light \& Traction Co., 52 Utah 210, 228, I73 Pac. 556, 563 (1918); Wishkah Boom Co. v. Greenwood Timber Co., 88 Wash. 568, 571, 579-80, I 53 Pac. 367, 368, 37 I (1915). Cf. Mount Vernon v. New York Interurban Water Co., II 5 App. Div. 658, 660-61, 101 N.Y. Supp. 232, 233-34 (rgo6); Wood v. New York Interurban Water Co., 157 App. Div. 407, 142 N.Y. Supp. 626 (Igr3). Occasionally such sentiments have found expression in the Supreme Court. See, for instance, Mr. Justice Miller's concurring opinion in Chicago, M. \& St. P. R. Co. v. Minnesota, I 34 U.S. 418 , at 459 (I890): "Neither the legislature nor . . . commission . . . can establish arbitrarily and without regard to justice and right a tariff of rates . . . which is so ... exorbitant and extravagant as to be in utter disregard of the rights of the public for the use of . . . transportation [facilities]. . ..." See, too, the similar hints in Washington ex rel. Stimson Lumber Co. v. Kuykendall, 275 U.S. 207 (I927). 
variety of reasons. Many of them require little discussion. One can, for instance, dismiss the Minnesota court's counsel of convenience-that if each consumer were free to seek judicial redress against unconstitutionally high rates there would be neither stability nor uniformity in the rate structure ${ }^{\mathrm{x}}$ - as summarily as that court dismissed some of its sisters' contentions that the utility's right to protection flows from its duty to serve ${ }^{\mathrm{x}}$ which has no counterpart in a consumer's duty to buy. ${ }^{20}$ To the former an adequate answer is a simple non credo. To the latter the answer is not only that given by the Minnesota court:

We are not strongly impressed with the proposition that, at the present time, the inhabitants of our large cities can dispense with the utilities supplied by the public service corporations, if the price seems too high. They are dependent upon these corporations for matters of daily need and comfort, such as light, water, power, and the like. If these necessities may be obtained only upon the payment of exorbitant prices, it really results in an enforced taking from the consumer of whatever he pays in excess of a reasonable compensation ${ }^{2 x}$

but as well that, today at least, price regulation and duty to deal are not coterminous. ${ }^{22}$ The price at which a milk dealer, for instance, may sell his product and the price which he must pay for his raw materials are both regulated. In neither case is the dealer forbidden to select his customers or his suppliers. Conversely, the Constitution, as it has been construed, does not allow a state to confront every entrepreneur with a choice between what-

${ }^{28}$ St. Paul Book \& Stationery Co. v. St. Paul Gaslight Co., I30 Minn. 71, 75-76, 153 N.W. 262, 264-65 (I915).

rg Is this not an inversion of the common law's teaching that the duty to serve carried with it, as a means of reinforcing it, the duty to serve at reasonable rates? Allnutt v. Inglis, I 2 East 527 (K.B. r8 ro). See Kirkman v. Shawcross, 6 T.R. I4, I7 (K.B. r794) (per Lord Kenyon, C. J.: "The case of the innkeepers does not bear any resemblance to the present; for as they cannot refuse to receive guests, so neither can they impose unreasonable terms on them").

${ }^{20}$ Birmingham v. Southern Bell Tel. \& Tel. Co., 234 Ala. 526, 534, 176 So. 301, 307-8 (r937); Brooklyn Union Gas Co. v. New York City, 50 Misc. 450, 46r, roo N.Y. Supp. 570, 577 (S. Ct. 1906); United States Light \& Heat Corp. v. Niagara Falls Gas \& Electric Light Co., 47 F. (2d) 567,570 (C.C.A. 2d $193 \mathrm{I}$ ). See Pinney \& Boyle Co. v. Los Angeles Gas \& Electric Co., I68 Cal. I2, I5, I4I Pac. 620, 62I (I914) ("Moreover, while the public utility is bound to render the service or furnish the commodity, an individual member of the public is not compelled to accept the service or use the commodity. If he does so it is conclusively held that his act is an acceptance of the rate fixed and that he may not, thereafter, contest the reasonableness of the rate").

2x St. Paul Book \& Stationery Co. v. St. Paul Gaslight Co., r30 Minn. 7r, 75, I 53 N.W. 262, 264 (1915). See, also, Western Association of Short Line Railroads v. Railroad Com'n, 173 Cal. 802, 806, I62 Pac. 391, 392 (1916): "Modern transportation has unquestionably reached the point where it is no more an answer to the farmer who thinks that the rates of the auto truck which passes his farm are extortionate, to say that he may haul his own product, than it would be to make him the same answer if he were complaining of a railroad extortion."

22 German Alliance Ins. Co. v. Lewis, 233 U.S. 389,407 (rgr4). 
ever rates it chooses to establish and going out of business or, to put it otherwise, it has not been supposed that one who is under no duty to deal may not protest against a legislative fixing of his prices. ${ }^{23}$

By the same token, it ought not to be difficult to convince a court that is not merely looking for phrases to justify its conclusion that the argument that the consumer has no "property" at stake to be protected ${ }^{24}$ is both untrue and irrelevant. It is untrue unless one closes one's eyes to the millions of dollars that consumers-domestic, mercantile and manufacturing alike-have spent in electrifying their homes, their stores and their factories, to the millions that they have sunk in gas-heating and watersupplying equipment, and to the millions irreparably put into sites that would be worth nothing if it were not for transportation facilities. If this be not property, this equipment which is good for nothing if the electricity, the gas, the water and the transportation are not forthcoming, then very little indeed can be called property. But the argument is as irrelevant as it is untrue unless one ignores the tens of dozens of cases on the books protecting expectancies-call them "property" if you will-which are fully as intangible as is this.

To deny that these arguments of the courts are convincing is not, however, to suggest that there are no difficulties to be hurdled. Beyond them lie several which are harder to overcome. One that might be thought to preclude, and certainly increases the difficulty of, judicial relief is familiar enough. Grovey v. Townsend, ${ }^{25}$ read in the light of Nixon v. Herndon ${ }^{26}$ and Nixon v. Condon, ${ }^{27}$ is a warning that the Fourteenth Amendment has limits, that a person who finds himself as effectively harmed by unofficial action as he could be by official action may find no judicial relief available against the former comparable to that which would lie against the latter. But granting, for the sake of argument, that Grovey v. Townsend is good law, its teaching must not be too hastily translated to cover our problem. It is not clear that, in fact, a defense of no state action would be open in such a case as the one we are supposing. Only rarely would it be clearly open-only, that is, where the utility enjoys its monopoly without any

${ }^{23}$ Cf. Tyson v. Banton, 273 U.S. 418 (1927); Ribnik v. McBride, 277 U.S. 350 (1928); Williams v. Standard Oil Co., 278 U.S. 235 (I929).

24 Brooklyn Union Gas Co. v. New York City, 50 Misc. 450, 100 N.Y. Supp. 570 (S. Ct. 1906), aff'd II 5 App. Div. 69, 100 N.Y. Supp. 625 (I906), aff'd I88 N.Y. 334, 8I N.E. I4I (1907); United States Light \& Heat Corp. v. Niagara Falls Gas \& Electric Light Co., 47 F. (2d) 567 (C.C.A. 2d 193I). Cf. Birmingham v. Southern Bell Tel. \& Tel. Co., 234 Ala. 526, 533 , 76 So. 301,306 (1937) ("a subscriber who has no invested capital at stake, but only a desire for a lower rate").

$$
25205 \text { U.S. } 45 \text { (1935). } \quad{ }^{26} 273 \text { U.S. } 536 \text { (1927). } \quad{ }^{27} 286 \text { U.S. } 73 \text { (1932). }
$$


official grant or sanction and makes its charges at its own will with neither permission nor denial by the state. In most cases, on the contrary, it ought not to be hard to find enough state action to satisfy the requirements of the Amendment. One ought to be able to find state action in the grant, as in many cases, of an exclusive franchise. ${ }^{28}$ One ought, too, in most cases to be able to see state action in the statutory requirements that rate schedules be filed and, as filed, adhered to. And if, as in many cases, the rates are not merely filed but are actually prescribed, the requirements could certainly be thought to be fulfilled. The question is not so much whether there is no state action or some state action as it is whether what state action there is is enough to warrant bringing the Fourteenth Amendment into play.

The issue is, in some ways, still more subtle than this. It is not true that the Supreme Court never compels a state to act or to redress its nonaction. Many times, of course, the problem need not be put in this form. Courts that possess adequate common law powers need not, ordinarily, be asked to face it in this way. ${ }^{29}$ They can, if they are state courts, act for the state. They can, if they are federal courts, do the same in the absence of state adjudications to the contrary. It is only when common law methods are absent-when, that is, neither common law nor statute gives a remedy - that the issue must be met head on. Though it is so frightening to think of its attempting to compel a legislature to act that it might be impossible to induce the Court to do anything about it, ${ }^{30}$ the problem has been thought simpler when the antagonist is a less formidable body. We are used, of course, to federal control of state judicial procedure in the name of due process of law. The indirect sanction of refusing to allow a judgment given after improper procedure to stand is common enough. ${ }^{3 x}$ If this sanction is not sufficient, the Court is armed, as Mr. Justice Johnson illuminatingly pointed out in his concurring opinion in Martin $v$. Hunter's Lessee, ${ }^{32}$ with the power to enter and to enforce against the

${ }^{28}$ Common law judges have found enough in the grant even of a non-exclusive franchise or of eminent domain powers to warrant placing the grantee under judicial price restrictions. Allnutt v. Inglis, I 2 East 527 (K.B. I8ro). Cf. Lumbard v. Stearns, 4 Cush. (Mass.) 60 (1849).

${ }_{29}$ The illustrations are many, but of them Int'l News Service v. The Associated Press, 248 U.S. 215 ( 1918 ), with Holmes' concurring and Brandeis' dissenting opinions, is particularly valuable.

${ }^{30}$ The hesitation of the Court in Virginia v. West Virginia, 206 U.S. 290 (1907), 220 U.S. I (IgIr), 222 U.S. I 7 (IgIr), 23 I U.S. 89 (IgI3), 234 U.S. II 7 (IgI4), 238 U.S. 202 (IgI5), 24 I U.S. 53 I (Igr6), 246 U.S. 565 (1918), is notorious.

${ }^{31}$ E.g., Powell v. Alabama, 287 U.S. 45 (1932) (failure of state court to provide counsel for accused).

${ }^{32}$ I Wheat. (U.S.) $304,362,365-67,38 \mathrm{r}-82$ (1816). 
parties a final judgment of its own. ${ }^{33}$ Beyond these cases are thosearising alike under the full faith and credit clause, ${ }^{34}$ the due process or equal protection clauses, ${ }^{35}$ and federal statutes ${ }^{36}$-in which a state court, holding that it was not endowed by its creator with jurisdiction over a cause, has nevertheless been ordered to assume such jurisdiction by the Supreme Court. Finally, there is such a case as CIO v. Hague in which positive police protection was ordered, ${ }^{37}$ or that whole line of cases following Gelpcke v. Dubuque ${ }^{38}$ which allowed federal courts to order tax assessments to pay judgments against municipalities. ${ }^{39}$ The point is, of course, that the Court can and does make use of established instruments which are accustomed to, or can be forced into, obedience to its mandate.

\section{II}

Constitutional difficulties of this sort need not, of course, be faced by a court which is armed with statutory authorization to reverse a public service commission. The constitutional question-just as it is, in any case of this sort, a method for getting into some court without the aid of statute -is, in such a case, hardly more than a means for getting into the Supreme Court. The statutes come in various forms. With those that define with some care who may appeal there has been little trouble; one who has been a party before the commission has little difficulty getting into court under them. ${ }^{40}$ More interesting are those instances in which the commission

${ }^{33} 43$ Stat. 937 (1923), 28 U.S.C.A. \&344(a) (1928). Tyler v. Magwire, I7 Wall. (U.S.) 253 (1872).

${ }^{34}$ Kenney v. Supreme Lodge, L.O.O.M., 252 U.S. 4II (I920); Broderick v. Rosner, 294 U.S. 629 (1935).

35 Truax v. Corrigan, 257 U.S. 3 12 (1921).

${ }^{36}$ Mondou v. New York, N.H. \& H.R. Co., 223 U.S. I, 55-59 (I912); Missouri ex rel. Burnes Nat'l Bank v. Duncan, 265 U.S. I7 (1924); McKnett v. St. Louis \& S.F.R. Co., 292 U.S. 230 (1934).

${ }^{37}$ The opinion of the trial court, 25 F. Supp. 127 (N.J. 1938), does not mention this important matter, but its decree is clear nevertheless; $\rightarrow$ The Hague Injunction Proceedings, 48 Yale L. J. 257, 268 (1938). The decree, after modification, was affirmed in ror F. (2d) 774 (C.C.A. 3d 1939) and 307 U.S. 496 (1939).

${ }^{38}$ I Wall. (U.S.) 175 (1863).

${ }^{39}$ The cases are legion, but Galena v. Amy, 5 Wall. (U.S.) 705 (1866), and United States v. New Orleans, 98 U.S. 38I (1878) (with which compare Heine v. The Levee Com'rs, ig Wall. (U.S.) 655 (1873)) are typical.

40 Allen v. Railroad Com'n, 79 Cal. 68, 175 Pac. 466 (Igr8), cert. den. 249 U.S. 6or (1919) ("any party to the action or proceeding [before the commission]"); Wichita v. Hussey, 126 Kan. 677, 27I Pac. 403 (1928) (inter alia "any body politic or municipal organization" may complain to the commission and "Any .... public utility .... or other party in interest" may appeal); In re Petition for Increase of Street Car Fares, I79 N.C. I5I, I0I S.E. 619 (1919) ("any party affected"); Erie City v. Public Service Com'n, 278 Pa. 512, 123 Atl. 47I (1924) 
acts sua sponte, the applicant before the commission is the utility, or the statute does not prescribe any qualifications for those who would protest the commission's orders. The extremes in the range of possible decisions under these circumstances are represented by the positions that have been taken by the New Jersey and the Minnesota courts. The former, operating under a statute which makes no pretense of defining who may seek a review of a commission's order, has permitted a person described simply as "a resident, citizen, and owner of real estate in Jersey City, in which some of the lines of the railway run" to contest an order increasing rates. ${ }^{4 x}$ The latter, operating under a statute which allows an appeal only to a party to a proceeding before the commission, has denied the right of appeal to a city which was notified by the commission of the pending proceedings, appeared on behalf of itself and of its citizens, took part in the proceedings and cross-examined witnesses. ${ }^{42}$ That neither conclusion is dictated by the

("any party to the proceedings affected thereby"); Public Utilities Com'n v. Providence Gas Co., 42 R.I. I, 104 Atl. 609 (IgI8); Attleboro Steam \& Electric Co. v. Public Utilities Com'n, 46 R.I. 496, I 29 Atl. 495 (1925), aff'd on interstate commerce issue 273 U.S. 77 (r927) ("any complainant aggrieved by any order"; intervening complainants treated as complainants); Railroad Com'n v. Houston Chamber of Commerce, r 24 Tex. 375, 78 S.W. (2d) 59r (r935) ("any .... party at interest ... . dissatisfied"; [for the chamber of commerce's position before the commission, see the latter's opinion and order, Sugar and Molasses, Carload, 37 Tex. R.R. Com'n Ann. Rep. 447 (1928); for a follow-up of this case, see Gulf, C. \& S. F. R. Co. v. American Sugar Refining Co. I30 S.W. (2d) I030 (Tex. Civ. App. 1939), dealing with the problems of collecting under- or over-charges for the period of litigation]); Eau Claire v. WisconsinMinnesota Light \& Power Co., I 78 Wis. 207, I89 N.W. 476 (1922) ("any person or corporation in interest being dissatisfied"); McLean Lumber Co. v. United States, 237 Fed. 460 (D.C. Tenn. Igr6) ("any party .... in interest to the proceeding before the Commission"); Anchor Coal Co. v. United States, 25 F. (2d) 462, 478 (D.C. W.Va. 1928), rev'd because moot 279 U.S. 812 (I929); Saxton Coal Mining Co. v. Nat'l Bituminous Coal Com'n, 96 F. (2d) 5 I 7 (App. D.C. I938) ("any person aggrieved by an order issued . . . in a proceeding to which such person is a party"). Contra: Seaberg v. Raton Public Service Co., 36 N.M. 59, 8 P. (2d) I00 (1932); In re Citizens of Belen and Valencia County, 37 N.M. r66, 20 P. (2d) 272 (r933). These cases, of course, do not go to the question of who is entitled to make himself a party before the commission or who can be said to be aggrieved or affected. As to this, see such cases as Public Utilities Com'n ex rel. O'Neil v. Marseilles Land \& Water Power Co., 295 Ill. 522, I 29 N.E. I 3 (I920) (holder of completely or nearly expired equity of redemption in land served by defendant not a proper complainant); Board of Railroad Com'rs v. Symns Grocer Co., 53 Kan. 207, 35 Pac. 217 (I894) (less than carload lot shipper cannot sue to enjoin enforcement of revised carload rate alleged to be discriminatory); Steenerson v. Great Northern R. Co., 69 Minn. 353, 372, 72 N.W. 713, 714 (1897) ("complainant before the Commission need have no direct or immediate interest in the matter, and even if [as here] he has, he is acting on behalf of himself and the rest of the public"); Cleveland v. Public Utilities Com'n, r27 Ohio St. 432, I89 N.E. 5 (1934) (city not entitled to make itself a party to proceedings begun by commission on its own motion and now finished which deal with "charges" and not with "rates").

${ }_{4 x}$ O'Brien v. Board of Public Utility Com'rs, 92 N.J.L. 44, I05 Atl. 132 (S. Ct. rgr8; aff'd without reference to this point 92 N.J.L. 587, 106 Atl. 4I4 (r9I9).

${ }_{42}$ State v. Tri-State Tel. \& Tel. Co., I46 Minn. $247,{ }_{7} 8$ N.W. 603 (I920). 
applicable statutes is indicated by results contrary to both in other jurisdictions. Thus the provisions of the Judicial Code governing review of orders of the Interstate Commerce Commission ${ }^{43}$ are of the same indefinite sort as that involved in the New Jersey case. Yet the Supreme Court, though it has agreed that one who contests an order of that commission on the ground that it is ultra vires need not have been a party to the commission's proceedings, ${ }^{44}$ has denied that right to a non-party where the question is merely one of reasonableness of rates. ${ }^{45}$ Per contra, the Rhode Island and Wisconsin courts, operating under statutes similar to that involved in the Minnesota case, have allowed persons, who so far as the reports show, were in the same position as the appellant in that case, to contest commission orders. ${ }^{46}$ This is not to say, of course, that the Minnesota court could decently have construed its statute to reach the result that the New Jersey court did if the New Jersey case had come before it. But it is to say that both types of statute are resilient enough to allow some thought to be given to what constitutes desirable procedure under them.

The result of the Minnesota decision is not only that unnecessary time, money and energy have to be wasted in all cases in which the original complainant drops out but that, in reality, no consumer's appeal at all will be available in those cases which the commission starts on its own motion. ${ }^{4 i}$ Whether one will wish to go as far as the New Jersey court has

${ }^{43} 38$ Stat. 219 (1913), 28 U.S.C.A. $\& 46$ (1927).

${ }^{44}$ Skinner \& Eddy Corp. v. United States, 249 U.S. 557 (1919) ("If plaintiff had sought relief against a rate or practice alleged to be unjust because unreasonably high or discriminatory the remedy must have been sought primarily by proceedings before the Commission. .... But .... [plaintiff's] contention is that the Commission has exceeded its statutory powers. .... In such a case the courts have jurisdiction of suits to enjoin the enforcement of an order, even if the plaintiff has not attempted to secure redress in a proceeding before the Commission."); see Edward Hines Yellow Pine Trustees v. United States, 263 U.S. 143,147 (1923). Cf. ICC v. Diffenbaugh, 222 U.S. 42 (IgII). But $\rightarrow$ Berger, Exhaustion of Administrative Remedies, 48 Yale L. J. 98I (1939).

45 United States v. Merchants \& Manufacturers Traffic Ass'n, 242 U.S. I78 (I9I6) (denying right to sue to one who was not a party before the commission); Youngstown Sheet \& Tube Co. v. United States, 295 U.S. 476 (1935) (permitting suit by one who was a party before the commission); see Alexander Sprunt \& Son, Inc. v. United States, 28I U.S. 249, 255 (I930).

${ }^{4}$ Public Utilities Com'n v. Providence Gas Co., 42 R.I. I, I04 Atl. 609 (1918); Attleboro Steam \& Electric Co. v. Public Utilities Com'n, 46 R.I. 496, I 29 Atl. 495 (1925); Eau Claire v. Wisconsin-Minnesota Light \& Power Co., I78 Wis. 207, I89 N.W. 476 (I922). The position before the commission in the Rhode Island cases is sufficiently indicated in the opinions of the court; for the Wisconsin case, see In re Application of the Wisconsin-Minnesota Light \& Power Co. for Authority to Revise Its Rates, 25 Wis. R.R. Com'n 88 (I920).

47 But cf. Wichita Railroad \& Light Co. v. Court of Industrial Relations, II 3 Kan. 217 , 237, 214 Pac. 797, 807 (1923): “. . . the evidence disclosed .... that the investigation of the contract rate was undertaken on the initiative of the Commission..... As we read the 
gone in allowing such appeals will depend largely on the situation in hand at the time. There is no difficulty in saying that a petitioner who wishes to present new evidence or to raise questions different from those which were presented before the commission should not be allowed to do so in court for the first time, that he should exhaust his administrative remedies before he comes there. ${ }^{48}$ But if everything that can be said before the commission has been said-if, that is, the appellant is willing to come to court on the record made before the commission whether by itself or by someone else-there is no good reason for requiring of him more than, at most, a pro forma application for a hearing before the board. To demand that he start a completely fresh application and, on that application, bear the burden of proof that a complainant normally bears is to ask far more than is necessary for the orderly administration of the law.

Some courts have found difficulties other than those centering around the word "party" in the way of granting to consumers the relief that the statutes would otherwise seem to authorize them to grant. Thus, in spite of the statutory authority of the Commerce Court to "enjoin, set aside, annul, or suspend, in whole or in part, any order of the Interstate Commerce Commission," ${ }_{49}$ the Supreme Court threw an obstacle in the way when, in Hooker v. Knapp, ${ }^{\circ 0}$ it held, on the authority of Procter $\&$ Gamble Co. v. United States ${ }^{5 \mathrm{x}}$ which was decided the same day, that the lower court had no jurisdiction to review an order of the commission reducing rates somewhat but not so fully as the consumer-plaintiffs desired. Though the affirmative-negative order doctrine of the Procter \& Gamble case has now been happily discarded in Rochester Tel. Corp. ग. United States, ${ }^{52}$ a problem which that case raised still remains. Statutory permission to set aside a

Utilities Act, there is no order, permissive or mandatory, which the Commission is authorized to make which cannot be challenged in a court of competent jurisdiction by any person aggrieved thereby. ...." Sections 21 and 40 of the act (Kan. Gen. Stat. Ann. [Corrick, r923] $\$ \$ 66-118,66-140$ ), which were specifically referred to by the court, provide that "any .... party in interest, being dissatisfied" may appeal and that the remedies given by the act shall be merely cumulative of other existing remedies. In spite of the sua sponte aspect of the commission's action it appears from the report of the case (at page 222) that the plaintiffs were notified of the proposed change and appeared in protest before the commission.

${ }^{48}$ Compare the problem of review where no record has been made before the commission, as, for example, where it merely allows a rate to be filed and to go into effect: West New York v. Board of Public Utility Com'rs, 8 N.J. Misc. 93, 148 Atl. 603 (S. Ct. 1930); Birmingham Slag Co. v. United States, ir F. Supp. 486 (Ala. 1935). Cf. Algoma Coal \& Coke Co. v. United States, in F. Supp. 487 (Va. I935).

${ }^{49}{ }_{3} 6$ Stat. I 488 (I9I I), 28 U.S.C.A. $\$ 4$ I (27) (r927).

s0 225 U.S. 302 (I9I2), reversing Hooker v. ICC, I88 Fed. 242 (Commerce Ct. I9II).

sI 225 U.S. 282 (I9I2).

52307 U.S. 125 (1939). 
rate order at the instance of a consumer no more solves all of the consumer's problems by itself than would a constitutional doctrine of extortionate rates. In either case one must ask what a striking down of a commission's rate order means. Probably one must distinguish between two cases. In the first of them the striking down of the order leaves standing a prior rate schedule which is sufficiently low to satisfy the constitutional or statutory requirements. There is, obviously, little difficulty for the court in such a case. It is the second that raises trouble: the order being struck down, there is left either a blank, or a still higher rate schedule,,$^{53}$ or a rate schedule which, though lower than the one struck down, is still too high under the tests set up by the court..$^{54}$ Within these cases, too, there are possible distinctions that must be drawn. There will be instances in which the utility will be willing to cooperate with the court-in which, to put it differently, it wishes the lower rates that the consumer is asking for and is, perhaps, merely using the consumer as a judicial cat's paw for its own end. ${ }^{55}$ All that is needed in such a case is a decree forbidding the commission to enforce its earlier order. There will be instances, too, in which the commission allowed the rates it did only under a misapprehension of what was required of $i^{56}$ and in which it has both the means and the will to tide over the interim. Again, the problems raised are not bothersome; a decree forbidding the utility to charge the filed rates and ordering the commission to proceed to correct its earlier findings is enough. It is only when utility and commission are actively opposed to court and consumer that one need fear trouble in framing and enforcing appropriate relief. There

s3 Cf. Public Service Gas Co. v. Board of Public Utility Com'rs, 84 N.J.L. $46_{3}, 87$ Atl. 65 I (S. Ct. 1913), rev'd as to refusal to review on certiorari and aff'd on merits sub nom. Passaic v. Board of Public Utility Com'rs, 87 N.J.L. 705, 95 Atl. 127 (1915). Cf. Pacific Gas \& Electric Co. v. Railroad Com'n, 16 F. Supp. 884 (Cal. r936), affirmed by an equally divided court 301 U.S. 669 (1937) (court may not refuse to enjoin enforcement of improperly adopted rate order on ground that prior schedule which will come into effect is excessive).

34 For the converse case-where the court's injunction, at the suit of a utility, against the enforcement of a commission rate order would have left in effect a still lower rate order-see Public Service Railway Co. v. Board of Public Utility Com'rs of New Jersey, 276 Fed. 979, 990 (D.C. N.J. 1921), appeal dismissed by stipulation 266 U.S. 636 (1924).

ss Such appears to have been the case in United States Light \& Heat Corp. v. Niagara Falls Gas \& Electric Co., 47 F. (2d) 567 (C.C.A. 2d 1931); see the master's report to the district court, 23 F. (2d) 719 (D.C. N.Y. 1927).

${ }^{56} \mathrm{Cf}$. New Orleans Real Estate Board vs. Ins. Com'n of Louisiana, I77 La. rogr, 150 So. 286 (1933); Brest v. Com'r of Ins., 270 Mass. 7, 169 N.E. 657 (1930); Brand v. Safford, I 18 Ohio St. 56, 160 N.E. 464 (1928). When, as in Allen v. Railroad Com'n, 179 Cal. 68, I 75 Pac. 466 (1918), it is held that a supplier of services is not, contrary to the commission's determination, a public utility and, hence, that the commission cannot relieve it from contract rates agreed to by it, there is, of course, no difficult administrative problem for the court. See also Oklahoma City v. Corporation Com'n, 80 Okla. 194, 195 Pac. 498 (1921). 
is, in such a case as this, the gentle method which several courts have suggested $^{57}$ and that most courts, without considering the matter, use: the court may, if it cares to, go on the assumption that the commission will do its duty as it is instructed by the court, that it will say, as Secretary Wallace said when his bona fides was challenged by plaintiffs who had been successful in overturning one of his orders:

Whatever may have been my findings on the basis of the prior hearing, I see no reason why I cannot as fairly and as impartially conduct further proceedings consistent with the opinion of the Supreme Court as any other inferior court whose action has been reversed by an appellate court. I, naturally, thought that my original decision was correct at the time. But $I$ have never said or intended to say that upon a further hearing with a new procedure or with the benefit of fresh argument or new evidence I could not or would not change my findings. In view of the defect found in my previous procedure and with the knowledge that my conduct of this proceeding will be most carefully scrutinized, I have every reason to guard against any possible error of procedure or of judgment. My concern is not to vindicate my past judgment, but to see that the substantive rights of the parties are fairly determined..$^{8}$

If, however, the commission cannot be relied upon to put a lower rate system into effect expeditiously-and ordinarily the court will have to give it considerable discretion in the matter-or, if, more than this, the commission is so hostile that only a mandamus will force it to do its job, there is indeed trouble to be faced, trouble that can be adequately met only if the court has an "or modify" clause at its disposal" ${ }^{59}$ or is willing to

${ }^{57}$ E.g., Hooker v. ICC, I88 Fed. 242, 247 (Commerce Ct. I9I I): “. . . . it appears that all the shippers would gain in this litigation would be the vacation of the [commission's] order, and if the court held that the rates permitted were so high as to be violative in a constitutional sense of the rights of the shippers then no doubt the Commission would not again establish such a high schedule of rates. .... At first we were inclined to think that the result which would be obtained by a successful termination of this suit in behalf of the shippers would be so inconsequential as to render it unnecessary for this court to take jurisdiction over the case, but upon further reflection it would seem that the shippers have the right to a judgment of this court as to whether or not the schedule of rates .... is [too] . . . high. . . . Then if the shippers again went before the Commission they would have the benefit of the judgment of this court upon that subject." Compare McLean Lumber Co. v. United States, 237 Fed. 460,468 (D.C. Tenn. I916): "The petition is not open to the objection that it seeks to have the court take the place of the Commission as a rate-making body, and require the Commission to order the railroad company to establish in lieu of the new rates such other and lower rates as may be found to be reasonable by the court. [It] .... merely prays that the orders of the Commission, affirmatively requiring the carrier to establish the new rates and maintain the same for two years, be annulled and their enforcement enjoined. ...."

${ }^{8}$ Secretary of Agriculture v. Andrews, mimeographed opinion, 4 (Bureau of Animal Industry, Docket No. 3II, I938).

59 See Van Buren Waterworks v. Van Buren, I52 Ark. 85, 89, 237 S.W. 696, 698 (1922). Cf. Steenerson v. Great Northern R. Co., 69 Minn. 353, 376, 72 N.W. 713 , 716 (1897), with which compare Duluth v. Railroad \& Warehouse Com'n, I67 Minn. 3II, 317, 209 N.W. 10, 13 (1926). 
reseise itself of its common law predecessors' powers and to require the utility directly not to charge unreasonable rates until the commission shall have framed a new and satisfactory rate schedule. ${ }^{60}$

${ }^{60}$ Cf. Hutchinson v. Hutchinson Gas Co., r 25 Kan. 346, 355-56, 264 Pac. 68, 73 (rg28); Consolidated Gas Co. v. Newton, 267 Fed. 231, 270, 273 (D.C. N.Y. r920), modified and affirmed 258 U.S. 165 (1922), with which compare Central Kentucky Natural Gas Co. v. Railroad Com'n, 290 U.S. 264 (1933). Contra: Garson v. Steamboat Canal Co., 43 Nev. 298, 185 Pac. 80I (I9I9); Railroad Com'n v. Uvalde Construction Co., 49 S.W. (2d) III3 (Tex. Civ. App. 1932) ("When rates are suspended by injunction, the old rates which were supplanted by those attacked thereby become effective. .... Whether or not such former rates are unreasonable .... becomes an entirely different controversy.... The entire matter .... reverts back to the commission for relief ....").

It is frequently said in the cases, of course, that rate-making for the future is "legislative" and that, therefore, the courts can do no more than declare a legislatively-designated rate void. This would seem to confuse the "properly legislative" with the "exclusively legislative." Compare three classes of cases: (I) Those in which the court has taken jurisdiction to determine the reasonableness of rates charged by municipally-owned utilities exempt from commission control: Kiefer v. Idaho Falls, 49 Idaho 458, 289 Pac. 8I (1930); Holton Creamery Co. v. Brown, 137 Kan. 418, 20 P. (2d) 503 (1933) (with which, however, compare Holton Creamery Co. v. Brown, I4I Kan. 830, 44 P. (2d) 262 (1935)); Butler v. Karb, 96 Ohio St. 472, 483, I 7 N.E. 953, 956 (191 7); Shirk v. Lancaster, 313 Pa. 158, I69 Atl. 557 (1933). See Oppenheim v. Florence, 229 Ala. 50, 57, 155 So. 859, 864 (1934); Springfield Gas \& Electric Co. v. Springfield, 292 Ill. 236, 253, I 26 N.E. 739, 746 (1920), aff'd 257 U.S. 66 (1921). (2) Those in which the court, admitting that rate-making is a legislative function, has nevertheless held itself entitled, where there was no commission control over a privately-owned utility, to enjoin discontinuance of service when the defendant-utility, charged by law with the exaction of no more than a "reasonable" rate, has threatened to exact an unreasonable one: Whitmore v. New York Interurban Water Co., 158 App. Div. 178, 142 N.Y. Supp. Iog8 (1913); Mamaroneck v. New York Interurban Water Co., 126 Misc. 382, 413, 21 2 N.Y. Supp. 639, 670 (S. Ct. 1925); Turtle Creek Borough v. Pennsylvania Water Co., 243 Pa. 40I, 90 Atl. 194 (I9I4) (with which compare Brymer v. Butler Water Co., 179 Pa. 231, 36 Atl. 249 (1897)); Ball v. Texarkana Water Corp., I 27 S.W. I068 (Tex. Civ. App. 1910) (with which compare West v. Probst, 6 S.W. (2d) 96, 105 (Tex. Com'n App. 1923)). Cf. People ex rel. Brush v. New York Suburban Water Co., 38 App. Div. 413,56 N.Y. Supp. 364 (1899) (mandamus to compel furnishing of water at reasonable rates). (3) Those in which the court, as a condition of the granting of an injunction against the rates set by a public service commission, has fixed the maximum rates chargeable by the utilityplaintiff pendente lite: Augusta-Aiken Railroad \& Electric Corp. v. Railroad Com'n, 28I Fed. 977 (C.C.A. 4th 1922); In re Arkansas Railroad Rates, r68 Fed. 720 (C.C. Ark. 1909); Public Service R. Co. v. Board of Public Utility Com'rs of New Jersey, 276 Fed. 979 (D.C. N.J. 1921), appeal dismissed by stipulation 266 U.S. 636 (1924); State ex rel. Cleveland v. Court of Appeals, 104 Ohio St. 96, 135 S.E. 377 (1922). Cf. Pacific Gas \& Electric Co. v. San Francisco, 21 I Fed. 202, 206 (D.C. Cal. 1913) (court will vacate injunction if unreasonably high rates are charged).

The classic discussion of the power of the legislature to impose rate-making duties on a court is that of Holmes, C. J., in Janvrin, Petitioner, 174 Mass. 514 , 55 N.E. 381 (1899). The discussion of McCurdy, The Power of a Public Utility to Fix Its Rates and Charges in the Absence of Regulatory Legislation, 38 Harv. L. Rev. 202 (1924), goes largely to the problem of whether the initiative lies with utility or court (and to that extent to the power of law as against that of equity), not to the power of equity to enjoin if the prerequisites for equity jurisdiction are otherwise present. Morrell v. Brooklyn Borough Gas Co., II 3 Misc. 65, I84 N.Y. Supp. 651 
III

The question remains by what standards a court is to judge whether a commission-made rate is so high that it ought to be struck down at the suit of a consumer. Passing by the problems that arise when the subject of the contest is an individual rate, the considerations involved can be seen in those larger cases that center around the utility's rate structure as a whole and that have been the main constitutional battleground in the fights between utility and commission. It is on this question of standards, one may venture to assert, that the possibility of getting a review on constitutional grounds breaks down. Probably the closest that one could come toward achieving this end-aside from the purely imaginative possibility of the commission's fixing a rate so high as to be absurd, e.g., \$1o per k.w.h. for electricity today - would be on demurrer. It is possible that sufficiently strong adjectives- "extortionate," "exorbitant," or "oppressive," for instance-could be found to induce a court to do for the consumer what it does for the utility on a plea of "confiscatory." For there is sometimes a magic in bare words that disappears when a more definite formulation is called for. But that the magic of "confiscatory"-arising as it does out of a persistent belief in property as a res rather than as a congeries of relations-has led the courts into an attempt to find a formula by which to settle the problem of the little more and the little less that is so critically pervasive of this field of constitutional law, is hardly a reason to hope that "oppressive" and its fellows which deal with intangibles will

(S. Ct. 1920), r95 App. Div. I, r85 N.Y. Supp. 883 (1921), 23 I N.Y. 398 , r32 N.E. r 29 (1921), which furnishes the starting point for his discussion, is not an altogether clear case. The New York Court of Appeals answered the first question certified to it- "On the complaint and moving affidavits, had the court at Special Term power to grant the injunction pendente lite against the defendant gas company, and to enjoin it from collecting the rate of $\$ 1.40$ per thousand cubic feet of gas?"-in the negative. (With this answer fell, of course, the affirmative portion of the trial court's injunction which fixed the rate at \$I.I5.) In doing so it did not refer to the allegations of the complaint "that the rate of one dollar and forty cents fixed by the order of the commission is unjust, unreasonable, excessive and exorbitant" but dealt solely with the question whether the commission had any power to fix a rate above a legislatively-declared maximum which had been held unconstitutional in another litigation. A sufficient answer may be that the commission was not a party to the injunction proceedings and that, until it was brought in, the company was entitled to rely on its filed and accepted rates. Another answer may be that, as pointed out by the dissenting justices in the Appellate Division ( $195 \mathrm{App}$. Div. I, 9 (I92I)), the proper method of correcting the error, if the commission had power at all, was by certiorari. Still another may be that counsel did not intend and the courts did not understand the allegation quoted above to be more than an inducement to equitable relief against the alleged excess of power assumed by the commission. But it is not impossible to believe that the Court of Appeals' opinion means that the trial court had no power at all to do what it did. If so, the case is in conflict with others cited above. 
cause the courts to indulge in similar efforts. At least, as utility and consumer alike have discovered to their sorrow, ${ }^{6 r}$ the effect of "confiscatory" in tangibles has not been carried over to intangibles on the procedural side of due process. Clearly, whatever may be the result in the statutory cases, one could not expect the courts to hold, as a matter of constitutional law, that the state's privilege is the exact measure of its duty, that the lowest rate which it may set without the utility's being able to protest successfully is the highest rate it may set without the consumer's being able to do the same. And above this there is-again without regard to the results in the statutory cases-no discernible stopping place that fits our habits of thinking. Even granting, then, that other difficulties in the way of relief to consumers can be successfully hurdled and granting, too, that the Court, though less given to the exercise of power in the name of the Constitution, might be presumed to be more indulgent to the consumer than it formerly was, one must probably conclude that the difficulty of finding a tenable formula renders the hope of effective constitutional review nil.

Except that they are not very explicit about the rates which the commissions are to set, the statutes may provide the needed leverage that the Constitution does not. "Just and reasonable" is the phrase which is usually employed to describe these rates-a phrase which, like so many other terms in the law, is one that has content only as content is given it. A statute which goes beyond this will hardly move further than the almost equally vague injunction that in fixing these "just and reasonable" rates due consideration be given to the value of the utility's property ${ }^{62}$ Unless, then, one is prepared to assert that there is such a thing as an "inherently just" rate or a rate which is "reasonable per se" one must be prepared to look elsewhere than to the statutes for help.

There is more than one verbally identifiable stopping place in the scale of possible rates which a court might say marks the "reasonable" price. Were one forbidden, as a consumer, to interest oneself in the earnings of the utilities and to base one's claim of too high rates on those earningsas, indeed, some of the older cases held ${ }^{6}{ }^{2}$ one might be nearly stranded.

6x Acker v. United States, 298 U.S. 426 (1936); Lewistown v. Public Service Com'n, 80 Pa. Super. 528 (1923); Scranton v. Public Service Com'n, 80 Pa. Super. 549 (1923). But cf. Huntington v. Public Service Com'n, 89 W. Va. 703, 706, r ro S.E. 192, I93 (1921) (semble that judicial review for consumers is required by the Constitution).

${ }^{62}$ Cf. Spurr, The State Commissions are Corrupting Utility Officials, 3 Pub. Util. Fort. 6r, 63 (1929).

${ }^{63}$ Canada S. R. Co. v. Int'l Bridge Co., 8 A.C. 723 (P.C. $188_{3}$ ); Hooker v. ICC, 188 Fed. 242 (Commerce Ct. rgir). 
But one might, under such circumstances, if one wished to indulge one's love of the obscure, point to the "value of the service" as the proper point. ${ }^{64}$ Or one could adopt some sort of quantum meruit technique and, with all the difficulty that such a search implies, go looking for the prices of similar services under similar conditions. ${ }^{65}$ Similarly one could, as some say the Massachusetts commission does, ${ }^{66}$ set one's face primarily toward maintaining the utility's securities at par on the market and allow a rate structure accordingly. Though one may doubt whether our public utility statutes were drafted on the assumption that the American businessman is so incapable of looking out for himself that, unlike the economic man of the textbooks, he will not pursue the goal of maximizing his profits without governmental pressure on him to do so, one might argue that he is in fact so incapable, and so proceed to the conclusion, as President Hadley and Professor Cabot do, ${ }^{67}$ that the policy-favored rate is one which will yield that result which would be had if the businessman attempted to maximize profits, the assumption being that thus, and thus only, can the utility's owners be induced continuously to improve and extend the service. Or one could, if this were too strong a dose, modify it by saying that that is a reasonable rate which, allowing for the fallibility of ownership and management, gives the utility enough but only enough

${ }^{64}$ I do not mean by this, of course, that "value of the service" cannot be made less obscure than it is. For one such attempt, $\rightarrow$ Fisher, Value of the Service and Public Utility Rates: Two Case Studies, I I J. of Land \& Pub. Util. Econ. 76 (I935). I mean merely that, at present, it has no well-defined meaning. See, on the subject in general, 2 Bonbright, The Valuation of Property 1 ro8 (19: $\rightarrow$ Edgerton, Value of the Service as a Factor in Rate Making, 32 Harv. L. Rev. 5r6, 534-56 (r9: $\rightarrow$ Heyman, The Value of the Service: Its Various Meanings and Uses, $9 \mathrm{~J}$. of Land \& Pub. Util. Econ. 252 (r933); Spurr, The $\$ 500$ House Telephone, I 2 Pub. Util. Fort. 320 (1933); Fisher, That $\$ 500$ House Telephone, I 2 Pub. Util. Fort. 586 (1933).

${ }_{65}$ Cf. Turner v. The Connecticut Co., 9r Conn. 692, 699, ror Atl. 89, 9r (r9I7) ("If a rate in one locality is largely in excess of rates in other localities similarly situated and subject to like conditions, it is an unreasonble rate, for this would instance a discrimination against one locality in favor of another, or other localities"). For a bona fide quantum meruit case adopting this technique in part, see Continental Trust Co. v. United Railways \& Electric Co., 7 F. Supp. 265 (Md. 1934). Both of these cases involve only individual rates.

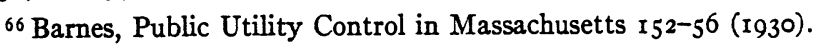

${ }_{67}$ Cabot, Public Utility Rate Regulation, 7 Harv. Bus. Rev. 257, 413 (1925); Ethics and Politics, 142 Atlantic Monthly 686 (rg28). Hadley, Principles and Methods of Rate Regulation, 16 Yale Rev. (n.s.) 416, 427-29 (1927); The Meaning of Valuation, I8 Am. Econ. Rev. (Supp.) 1 73, 178 (1928); testimony in 2 Report of Commission on Revision of the [New York] P. S. C. Law, 722, 735-36, 743-44, 747-48 (1930). For criticisms of these two authors $\rightarrow$ Boatwright, Competition and Electric Rates, 7 J. of Land \& Pub. Util. Econ. 18r (193r); Bonbright, The Basis of Rate Control, in I Report of Commission, etc. ut supra, 334, 374-77; Gray, Competition as a Basis for Electric Light and Power Rates, 5 J. of Land \& Pub. Util. Econ. 243 (r929); Ryan, Public Utility Rate Regulation, 8 Harv. Bus. Rev. 193 (1930); Spurr, op. cit. supra note 62 . 
to provide continuous encouragement for nobler and nobler work. ${ }^{68}$ One could, if one accepted the ethical "ought" that is caught up in the assertedly scientific "is," urge that, since the best of all possible worlds for distributing energies, resources and rewards is a competitive world, the utility should be permitted to earn what it would earn if such a regime were present even though the utility is blessed, by grace or otherwise, with its absence. ${ }^{69}$ (Here, of course, one would be careful to define competition so that it was a properly decorous competition, not the horrendous variety that occasionally crops up in the cases; $;^{70}$ the latter, if it were accepted as a norm, might justify the commission in fixing rates closer to zero than would be comfortable.) Or one could, if one thought this last were too good or too bad for the utility, add to or subtract from it, as the case may be, whatever extra costs or savings occur from the utility's being in a monopoly position. Not finally, but lastly, one might (if only one had a subsidy at hand) urge, following the analysis of Professor Montgomery, ${ }^{7 \mathrm{x}}$ that the rate should be so fixed as to evoke an expanding demand, the limit of which would be at "the point where incremental cost and demand price coincide" and that, absent such a subsidy, the closer one approaches this goal without running into constitutional difficulties the better.

But the courts' answers, in practice, to the inquiries which such a phrase as "just and reasonable" must raise are not so multiform as might be expected. The tendency is ${ }^{72}$ to lay down much the same criteria that have

${ }^{68}$ Cf. Bussing, Public Utility Regulation and the So-Called Sliding Scale (passim) (1936).

${ }^{69}$ This appears to be the view of at least some of the apologists for the reproduction cost doctrine. Cf. Brown, Discussion of Bonbright's Railroad Valuation with Special Reference to the O'Fallon Decision, I8 Am. Econ. Rev. (Supp.) I8I (1928); Railroad Valuation and Rate Regulation, 33 J. Pol. Econ. 505 ( $19: \rightarrow$ Dorety, The Function of Reproduction Cost in Public Utility Valuation and Rate Making, 37 Harv. L. Rev. 13 (1923). Not an apologist for reproduction $\mathrm{c} \rightarrow$ Kirshman, The Principle of Competitive Cost in Public Utility Regulation, 35 Yale L. J. 805 (1926), also accepts competitive price as the norm ("Regulation of public utilities in the United States has as its deepest purpose the perpetuation of ideals and standards attained in the field of natural competition").

${ }^{70}$ Cf. Public Service Com'n v. Great Northern Utilities Co., 289 U.S. 130 (1933) (private competition); Seymour v. Texas Electric Service Co., 66 F. (2d) 8I4 (C.C.A. 5th 1933), cert. den. 290 U.S. 685 (1933) (municipal competition); Mapleton v. Iowa Public Service Co., 209 Iowa 400, 223 N.W. 476 (1929) (municipal competition); Great Northern Utilities Co. v. Public Service Com'n, 88 Mont. I80, 293 Pac. 294 (1930) (private competition); Community Natural Gas Co. v. Natural Gas \& Fuel Co., 34 S.W. (2d) 900 (Tex. Civ. App. 1930) (private competition). $\rightarrow$ Gray, Public Utility Competition: A Case Study, I $_{5}$ J. of Land \& Pub. Util. Econ. 195 (1939).

${ }^{7}$ Government Ownership and Operation of Railro: $\rightarrow$ 201 Annals Am. Acad. of Pol. \& Soc. Sci. 137 (1939).

${ }^{72}$ Wheeling v. Natural Gas Co. 115 W. Va. I49, 175 S.E. 339 (1934), appeal dismissed by agreement of parties 296 U.S. 659 (r935) (reversing commission for not considering original 
been adopted in those cases in which the courts have had to decide for themselves in the first instance what such a rate is. ${ }^{73}$ And these, in turn, run in much the same terms as those that survive from Smyth v. Ames. ${ }^{74}$ The result is that, though there is some talk of reasonableness as a zone rather than a line, ${ }^{75}$ the zone, in most cases in which it emerges, will have to arise out of tolerance in the application of formulae ${ }^{76}$ rather than out of a difference in the formulae themselves.

Off-hand it would, indeed, seem better to admit that the test of reasonableness is not the same when a consumer appeals as it is when the appellant is a utility. For it hardly follows that because the commission may forbid a utility to earn more than, say, six per cent on a $\$ 5,000,000$ rate base, it must do so-in other words, that anything above this is an un-

cost). See Public Utility Com'n ex rel. Springfield v. Springfield Gas \& Electric Co., 29r IIl. 209, 222, I 25 N.E. 891, 897 (1919) (city's appeal from lower court injunction against commissionfixed rates); Eau Claire v. Wisconsin-Minnesota Light \& Power Co., 178 Wis. 207, 216, 189 N.W. 476,480 (r922) ("We believe .... that [under] the legislative command to the commission .... the public has a right to complain of any rate which yields the utility more than a reasonable return. This is upon the theory that the legislature has in general terms prescribed but one rate: i.e., a reasonable rate ... ."). Cf. Huntington v. Public Service Com'n, 89 W. Va. 703, IIO S.E. I92 (I92I) (commission's order raising water rates suspended on finding that it will yield a return to the stockholders estimated at between nine and fourteen per cent though the net return on fair value is but seven per cent). Consult such cases as State ex rel. St. Louis v. Public Service Com'n, 34I Mo. 920, I IO S.W. (2d) 749 (1937), appeal dismissed sub nom. Laclede Gas Light Co. v. Public Service Com'n of Missouri, 304 U.S. 398 (1938); East Ohio Gas Co. v. Public Utility Com'n, 133 Ohio St. 21 2, I 2 N.E. (2d) 765 (1938); and Chambersburg Gas Co. v. Public Service Com'n, I 16 Pa. Super. 196, I 76 Atl. 794 (1935), in which there are appeals by both utility and consumer.

${ }_{73}$ Pere Marquette Boom Co. v. Adams, 44 Mich. 403, 6 N.W. 857 (I880) ("fair market value, arrived at with all such aids [including cost] as the circumstances afford"); Long Branch Com'n v. Tintern Manor Water Co., 70 N.J. Eq. 71, 62 Atl. 474 (Ch. r9o5), aff'd 7I N.J. Eq. 790, 7I Atl. II34 (I907) (fair value, but with emphasis on cost); New York Interurban Water Co. v. Mt. Vernon, I ro Misc. 28I, I80 N.Y. Supp. 304 (S. Ct. I920); Mamaroneck v. New York Interurban Water Co., I 26 Misc. 382, 398-40I, 212 N.Y. Supp. 639, 656-59 (S. Ct. 1925); Turtle Creek Borough v. Pennsylvania Water Co., 243 Pa. 40I, 90 Atl. I94 (rgr4); Wishkah Boom Co. v. Greenwood Timber Co., Ioo Wash. 472, I7I Pac. 234 (I918) ("present fair cash value, which is . . . . reproduction cost minus . . . . depreciation"). See Hall v. Tittabawassee Boom Co., 5I Mich. 377, 399, I6 N.W. 770, 782 (1883) (trial court's instructions to jury: "fair rental value of the property [for which "a reasonable expenditure" is permissible] used . . . . in their business"); Underwood Lumber Co. v. Pelican Boom Co., 76 Wis. $76,84,45$ N.W. I8, 2I (I890) ("value of all property and rights of property necessarily devoted or used" in the company's business).

74 r69 U.S. $466,546-47$ (1898).

75 Detroit v. Michigan Railroad Com'n, 209 Mich. 395, 433-34, 177 N.W. 306, 319 (1920); Portsmouth v. Public Utility Com'n, ro8 Ohio St. 272, I40 N.E. 604 (1923). See Commons, Legal Foundations of Capitalism 357 (1924).

${ }^{76} \mathrm{As}$, for instance, through the operation of the rules governing burden or quantum of proof in the court. 
reasonably high rate. The only immediately apparent objection to the double standard is that inquiry will be complicated and attention scattered by requiring the court to keep in mind two sets of criteria at once. But beyond this, can anything be said for adopting the same criterion for the consumer's appeal that exists in the utility-appellant case? The result makes sense as an expression of what generations of liberal economists and exponents of progress have preached as the great end and justification of private enterprise: as great a production of goods and services as possible. And this is not, one may argue, so far from the legal norms which are associated with public utilities as might be supposed. It is but putting into broader and more obviously ethical terms the rule from which the notion of reasonable rates got its common law start-the rule, that is, that it is the duty of the utility to serve. That duty which in earlier times was a duty to serve the occasional traveler on the highway, the casual applicant at the inn-keeper's door, the passing customer of the ferryman can thus be translated into the modern as the utility's duty to supply continuously those indispensable services typified by water, transportation, power and light on which whole communities are dependent. The utility's duty to serve, read in this context, is a duty so to price its services that as large a proportion of the community as possible shall have as full access to them as possible. ${ }^{77}$ And it is, so it may be argued, the commission's duty under the statutes to see that this duty is enforced. It is its duty, to rephrase the matter, to see that in the absence of unusual circumstances rates are kept as low as the Constitution will allow them to be kept. ${ }^{78}$ To adopt such a rule ought not to mean, of course, that there would be no flexibility in its application. There would clearly be circumstances, for example, under which the commission, seeing the impossibility of keeping the utility alive if rates were pared as low as they might be, would be justified in not doing so. There ought to be no difficulty again - if provision could be made ahead of time for keeping such forced contributions out of the rate basein permitting the utility to finance extensions out of present rates instead of on the capital market. And there should be no trouble, for a third example, in seeing that the income over a period of four or six or eight years

\footnotetext{
7 Merrill, On the Distinction between a Nonconfiscatory Rate and a Just and Reasonable Rate, 14 Corn. L. Q. 447, 456 (1929), arrives at the same conclusion.

${ }^{78} \mathrm{An}$ underlying assumption, which is believed justified, is that the return to which the utility is constitutionally entitled is quite enough to protect the community's needs in keeping it going. See Merrill, op. cit. supra note 77; Lewis, "Reasonable" and "Barely Confiscatory" Rates, 15 Corn. L. Q. 573 (1930). Comf $\rightarrow$ Guernsey, The Test of Reasonable Rates, 14 Va. L. Rev. I (1927). Of course, if the constitutional bottom should drop out, it would be necessary to re-examine this part of the problem.
} 
may be a better measure for deciding whether rates are reasonable or not than is our more usual annual accounting period.

If this is the correct interpretation of the statutes, it seems clear enough that judicial review at the instance of a consumer is proper in a rate case. But "the correct" may be misleadingly simple. Can one say with complete assurance that there is no other "correct" interpretation?; that the policy of the statutes is so clear that the commission itself has no choice of policy to make? Probably it would be agreed that this is too broad a statement to stand. If so, it is not so clear that the consumer does have a judicial remedy open to him. For if we say that what is a "just and reasonable" rate is a matter of policy, we have practically committed ourselves to commission finality. If, on the other hand, we choose to call it statutory interpretation, we have opened the way for the court to intervene. The former result, in spite of the overturning of the affirmative-negative order doctrine, is probably the one to be anticipated in the Supreme Court. For we have been warned that

even when resort to courts can be had to review a Commission's order, the range of issues open to review is narrow. Only questions affecting constitutional power, statutory authority and the basic prerequisites of proof can be raised. If these legal tests are satisfied, the Commission's order becomes incontestable. 79

Whether the state courts will ignore this as they have ignored the affirmative-negative order doctrine in the past is anyone's guess. Whether they should ignore it-of course one assumes that there will be like treatment of consumer and utility whichever way they go-is another question. Its solution will depend in part on one's notions as to the propriety of an unsupervised and unlimited delegation of power in however small a field. ${ }^{80}$ It will depend partly on one's estimate of the value of having some statutory method of judicial review at the instance of a consumer to counterbalance the utility's constitutional method and of being able to force the courts occasionally to look at a commission in a light other than that shed by utility-commission contests. And it will depend partly on one's estimate in a given jurisdiction and at a given time of the faithfulness of a particular commission to its statutory duties. Of such must one's judgment be compounded.

\footnotetext{
79 Rochester Tel. Corp. v. United States, 307 U.S. 125, r39 (r939).

${ }^{80}$ So it might be argued, for instance, that because a statute which does not in terms or by implication set a standard by which the commission is to fix rates (and thus give the courts a standard by which to determine whether the commission has exceeded its authority) involves an undue delegation of power-cf. Matter of Saratoga Springs v. Saratoga Gas Co., I 22 App. Div. 203, 214-15, 107 N.Y. Supp. 34I, 349-50 (1907), rev'd on other grounds 19r N.Y. I 23, 83 N.E. 693 (1908) - the courts are required to determine whether that authority has in fact been exceeded in order to avoid the standard's being rendered meaningless in practice.
} 